\title{
Do Peer and Family Factors Determine Substance Abuse? \\ Voices of Adolescents Undergoing Treatment in a Psychiatric Ward, Lagos, Nigeria
}

\author{
Samuel Ojima Adejoh, Adetayo Olorunlana², \\ Waziri Babatunde Adisa', Oluchi Onwuasoanya' \\ ${ }^{1}$ University of Lagos, Akoka-Yaba, Lagos, Nigeria, ${ }^{2}$ Igbinedion University Okada, \\ Benin City, Edo State
}

\begin{abstract}
Background: Although studies on drug abuse among adolescent are abound, there is however limited works on the life experiences of drug abusers, undergoing treatment in a psychiatric ward in Lagos, Nigeria. This study explored the experiences of drug abusers on whether family and peer influences are factors of predispositions and consequences of drug abuse in Lagos, Nigeria. Methods: Using purposive sampling, 20 adolescents receiving medical attention for at least 6 months in a psychiatric ward of a teaching hospital participated in the in-depth interviews which were audio-recorded. Data were content-analysed using exploratory design. Results: Participants ranged in age from 14 to 18 years old, and all were receiving psychiatric treatment in a hospital ward. Findings indicated that participants' were pressured into drug use by peers, to enhance performance, parental neglect and relatives using or abusing a substance. Participants abused illicit drugs and over the counter drugs among others. Consequently, they got addicted, and their behaviours were negatively impacted. All participants reported they were taken to the psychiatric ward because of their addiction to a certain psycho-active drug that affected their cognitive behaviour. Conclusion: There is a need for a continuous sensitization about the harmful effects of drug abuse to all the citizens. Parents should also be educated on the need to discharge their responsibility of caring for their wards. These findings have implication to the breaking of the cycle of drug addiction, and how to prevent future problems from drug abuse among adolescents.
\end{abstract}

Keywords: drug abuse, adolescents, peer pressure, Nigeria, domestic violence

Copyright $@ 2020$ KBCSM, Zagreb

e-mail: alcoholism.kbcsm@gmail.com•www.http://apr.kbcsm.hr

Correspondence to:

Samuel Ojima Adejoh, Ph.D.

Department of Social Work, Faculty of the Social Sciences

University of Lagos, Akoka-Yaba, Lagos, Nigeria

Phone: +234 8038-501-834

E-mail: sadejoh@unilag.edu.ng, samuelojima@yahoo.com

\section{Introduction}

Adolescence is one the critical stages in the development of an individual. It is critical because it is the stage at which an individual gets exposed to the culture of the larger society, the school, the bostal institution, and oth- 
er institutions of society. While they grow, individuals are expected to get acquainted with new life and new culture. One of the cultures that young people in the developed and developing countries learn, is the culture of drug taking and abuse. Although drug abuse exists all over the world, in recent times, the problem has become alarming in the developing countries where the state has failed to effectively control the act [1-3]. According to Akannam [4], the prevalence of drug abuse among drug users in Nigeria shows Northwest (37.47\%), Southwest $(17.32 \%)$, Southeast (13.5\%), North-central (11.71\%) and Northeast $(8.54 \%)$. It was estimated that about $70 \%$ of adolescents will have tried alcohol, half will have taken an illegal drug, nearly 40\% will have smoked a cigarette, and more than $20 \%$ will have used a prescription drug for a nonmedical purpose by their senior years in high school [5].

The increase in use, abuse and misuse of psychoactive substances though a global challenge of grave public health concern [6-9], the problem of drug abuse in Nigeria and in Lagos State cannot be overemphasised. Drug abuse continues to be the major risk behaviour among youth and adolescents, with mental health complications, academic problems, physical health impairment, stigmatization, family and social-economic problems, unemployment and delinquency $[10,11]$.

Abuse of illicit narcotics was described as a significant challenge, particularly in Rivers and Lagos States in Nigeria [12]. Alemika [13] affirmed that about $20 \%$ of the school population in Lagos State had taken a psychoactive drug once in their livetimes, a situation that has compounded over time, based on empirical evidences of the use and abuse of tobacco, cigarette, alcohol, marijuana, tranquilizers, kola nut, inhalants and cough syrups in various secondary schools and universities in Nigeria [14-16].

The city of Lagos is described as the hub for drug use for decades because of its strategic position as a commercial and entertainment centers, with its vibrant social and night life [17]. Drugs commonly abused in Lagos are choko, rochi, alcohol/cigarettes and marijuana and prescription drugs like pain relievers, tranquilizers and stimulants. The abuse of pharmaceutical products continues to grow among youth in Lagos. Codeine, a brand of cough syrup, tramadol, aspirin and pain-relieving drugs are common at Lagos parties. The pills are crushed and mixed with the cough syrup and then added to soft drinks or juice and it is served chilled in plastic cups at parties [18].

Between 2010 and 2012, six illegal methamphetamine factories were discovered in Lagos and Delta States. Again in January 2015, another methamphetamine factory was discovered in Lagos by the National Drug Law Enforcement Agency. In November 2017, the Police in Lagos raised an alarm at the ease with which the youth get access to drugs at clubs, hotels, lounges, beaches and bars [19]. Public commentaries have identified poor drug regulation, unemployment, disengaged and frustrated youth as some of the causes of drug abuse. Other factors are peer influence, broken homes, depression, curiosity, boldness and for enhancement in sport and sexual performance. The needs for social acceptability, to feel high or good, to relax or relieve tension or pain, to experiment and to feed addiction are some other reasons for drug abuse. However, studies have identified different factors in substance abuse such as the role of family structure [20-29].

Although public production and consumption of marijuana in Nigeria is illegal 
[30], it is probably the second most abused drug in Nigeria. According to NSRP report, aside from marijuana, the most commonly used drugs were said to be over the counter prescription medications such as tramadol, codeine syrup, Exol and Rohypnol [12]. These are all nominally controlled substances, only supposed to be taken according to doctor prescription and guidance. Similarly, alcohol is said to be the most common substance of addiction and a threat not only to health but also to sustainable human development [31].

Despite the magnitude of the problem, there are fewer studies in Nigeria that have explored the life experiences of drug abusers. For this study, we explored the experiences of drug abusers in Lagos Nigeria. We, particularly underscore family and peer influences that lead to their drug use, and the consequences of drug abuse. This is significant because any intervention that does not understand the problem cannot find a sustainable solution.

\section{Theoretical explanation}

The study is guided by the Differential Association Theory. According to the theory, people learn delinquent behaviours in the same way they learn non-delinquent behaviours. The theory posits that deviant acts are learned in intimate, face-to-face interaction with significant others or people to whom one is close. According to the theory, substance use is learned and reinforced within a group setting (peer or in the family) in which adolescents learn the intake of substance or drugs through encounter with people that are into drug intake. Future drug users interact with current users and learn appropriate definitions of the drug experience, which has a strong impact on their future experiences and behaviour. Using the Differential Association Theory, adolescents can engage in substance abuse as a result of the family they come from, which might be a family where substance or drug intake is common. According to Shuttleworth, young people smoke because of peer pressure in order to "belong" and not appear "different" among friends that smoke [32]. Others smoke to imitate their parents or other adults they admire. Hence adolescents engage in substance abuse as a result of their encounter with people that are also into the act of substance intake. This may range from family members, peers and people in the society at large.

\section{Methods}

The study used an exploratory research design, with the objective of finding out the causes and effect of adolescents' involvement in substance abuse. The setting of the study was the Psychiatric Ward of Lagos University Teaching Hospital (LUTH), Lagos State, Nigeria. Participants were recruited using a specific recruiting strategy already planned out to identify and enrol participants in the research study. The plans specify the criteria for participant eligibility, the location and the approached used. Based our scheduled consultations with the health personnel in the ward after securing ethical clearance from the hospital authorities, we were able to identify through hospital records the numbers of persons admitted for the use of psychoactive drugs that were undergoing treatment.

Participants were them carefully recruited based on certain characteristics. These include being a teenager, currently undergoing psychiatric treatment based on drug abused of any type. The participants comprises male 
and female who had been admitted and currently on admission in the hospital not less than 6 month and finally should be willing to share or state the reasons that led him or her to substance use. Data were collected using in-depth interview guide; conversations were audio-taped and lasted about 20 minutes with each participant.

We followed international and national guidelines for ethical conduct in research, which address the specific requirements for informed consent. Our informed consent centred on voluntary participation and the ability of the individuals or their surrogates to comprehend information about the study goals. Ethical clearance was obtained from the hospital ethical review board; consents were obtained from the participants. Participation was voluntary, participants were not manipulated but observed naturalistically, and anonymity guarantee and confidentiality of data were ensured.

Although, the hospital record had 50 adolescents receiving anti-psychiatric drug treatments at the psychiatry ward at the time of the study, only 20 participated. Eight were under sedative, 10 were too emotional to respond to our interview, and 12 others had their admission less than 6 months. The study sample population comprises 16 males and 4 females' adolescent receiving treatment at Psychiatry Ward LUTH. Age of the particpants ranged between 14 and 18 years old.

Braun and Clarke guide on conducting thematic analysis was used in the reading and coding of the in-depth interview [33]. We combined the technique of both inductive and deductive thematic analysis; transcription were coded by two members of the research team and corroborated by the third. The initial generated codes were 25 , these were then collated for specific themes using axial coding by reorganising and making connection between categories and sub categories, we generated five thematic categories. Further review and evaluation led to three final thematic categories presented here. To ensure coherence and maximum rigor, public health based organisation staff and independent researchers reviewed and validated the interpretation. Results were then content analysed.

\section{Results}

\section{Predisposing factors}

Three main themes emerge in our search for the causes of drug use and abuse among adolescents undergoing treatment at teaching hospital. They include peer influence, family disorganisation and single parenting.

\section{Peer influence}

Participants recount their experience and explain how they were introduced to different kinds of substance by their peers. Two sub-themes emerged from peer influence.

\section{The pressure to 'belong'}

The first category was basically teenagers who want to avoid being discriminated against, so the drives to belong to their subgroup constrain them to make use of the drug. According to one participant:

My friends do patronize people selling India hemp. I was forced to join them and started using alcohol because all my friends were drinking, and I felt left out, so I thought the only way to belong is to start drinking. So I joined them to feel belong and part of the group. (Male/18years) 
Table 1. Socio-demographic Characteristics of Participants

\begin{tabular}{|c|c|c|}
\hline Variables & Frequency & Percentages \\
\hline \multicolumn{3}{|l|}{ Sex } \\
\hline Male & 16 & 80.0 \\
\hline Female & 4 & 20.0 \\
\hline \multicolumn{3}{|l|}{ Age } \\
\hline 14 & 1 & 5.0 \\
\hline 15 & 2 & 10.0 \\
\hline 16 & 4 & 20.0 \\
\hline 17 & 4 & 20.0 \\
\hline 18 & 9 & 45.0 \\
\hline \multicolumn{3}{|l|}{ Education } \\
\hline Primary School & 3 & 15.0 \\
\hline Secondary & 7 & 35.0 \\
\hline Undergraduate & 10 & 50.0 \\
\hline \multicolumn{3}{|l|}{ Status } \\
\hline Unemployed & 4 & 20.0 \\
\hline Students & 11 & 55.0 \\
\hline Entrepreneur & 5 & 25.0 \\
\hline \multicolumn{3}{|l|}{ Substance abused } \\
\hline Codeine & 4 & 20.0 \\
\hline Tramadol & 2 & 10.0 \\
\hline Vodka & 2 & 10.0 \\
\hline Marijuana & 4 & 20.0 \\
\hline Flunitrazepam & 2 & 10.0 \\
\hline Beer & 2 & 10.0 \\
\hline Promethocen & 1 & 5.0 \\
\hline Alomo & 1 & 5.0 \\
\hline Cocaine & 1 & 5.0 \\
\hline Coffee & 1 & 5.0 \\
\hline \multicolumn{3}{|l|}{ Causes of Abuse } \\
\hline Peer pressure & 10 & 50.0 \\
\hline Boredom & 4 & 20.0 \\
\hline Family or relatives & 4 & 20.0 \\
\hline use & 2 & 10.0 \\
\hline \multicolumn{3}{|l|}{ Multiple factors } \\
\hline Total & 20 & 100 \\
\hline
\end{tabular}

Another participant was pressurized by his friends with all kind of mocking names that make him feel inferior, so, he had to join his friends to avoid continual discrimination and embarrassment. In his words:

It was my friend that advised me to hang out with them if I want to be a 'big boy'. I followed them and they bought alcohol for me, at first, I refused the offer, but they started calling names like 'Otay' (meaning 'novice') so in order for this to stop I had to start doing what they were doing. This made me part of their click. We go out a lot and on many occasions, we drink to catch fun. I continued until it became part of me, and I found myself always drinking, I became addicted to it. It became so bad my folks had to bring me here. (Male/16years)

\section{Drug as performance enhancer}

In order to belong to a group, some teenagers were influenced to take drug and alcoholic drink. However, others were involved in substance abuse for other reasons. For example, one participant was informed by his friends that substance used will help him become a music star. In order to enhance his performance, he began to take drug based on the advice of his peer. He claimed he was influenced and pushed by his friends into taking codeine and 'omi gutter' literally meaning drainage water, which is the combination of codeine, marijuana, vodkha, tramadol and 'igbo roots'.

He had this to say:

I am a young boy with dreams of going into music in life to do Hip-Hop. But the kinds of friends I have are alcoholics and smokers. All of us are into music and plan on going fully into it immediately after our secondary school education. At some point, we rehearse together but were told that if we are not 'high' with alcohol or 
smoke marijuana, that the inspiration will not be there and that our performance will be bad. They said 'if you don't take it, your performance will be affected'. I started following their steps and it seems everything was okay as my rapping skills improve and everybody hails me for a job well done. I started seeing the intake of alcohol and other substance as a contributor to my good performance in raping... (Male/18years)

Although the participant here was not interested in furthering his education, so his music friends influenced his use of drugs. There exists other contrasting data, of a participant who abused substance in order to have a good academic performance. She said:

I was influenced by my friends in taking Nescafe for all night reading in school. My friends told me that if I want to read well without dozing off in the night, I need to take Nescafe which they say will enhance my ability to read long. With this, I could not read without taking Nescafe and also take it to stay awake and do some other things. I started growing lean and could not remember much in the exam hall again. At some point, I slept off while the exam is still on. I started having insomnia. My course adviser called my Dad who brought me down here after telling my dad about some of the activities I engaged in and what is happening to me (Female/17years)

\section{Family disorganisation}

Reprimanding children is cultural in Africa when the child is not reprimanded; it is taken for granted that, his/her action is acceptable to the parents or guardians. The influence of family disorganisation in substance intake sometimes may not be an overt factor but a covert one. This can be explained by multiple factors. One participant observed thus:

My mother and father do not have time for me and as a result, I go out with friends to keep them company and they take alcohol to have fun. I took to the consumption of alcohol when I was 15 years, which my mother was aware of but did not say anything and at the onset; it was like as if I have seen life. At some point, my mum told me to stop taking alcohol and face my studies but I refused because it was as if she did not really mean it. (Male/18 years)

Parental neglect accounts for one of the reasons some children get involved with friends that are involved in substance abuse, who later introduce their wards or children to the same practice. One participant narrated her ordeal thus:

My parents never had my time. When I needed their care, they were nowhere to be found. They were nonchalant about my wellbeing. I have been taking care of myself right from childhood. After my admission to the University, I started going to the club where I learned to take alcohol. There was no one to talk to, so, I am always alone thinking. My parents are wicked they are very strict; they made me like this, and turn back to blame me for being an alcoholic, threatening to disown me. (Female/14years)

Similarly another participant stated thus:

I was 14 years when I left secondary school. My mother took me to my aunt because she could not afford taking care of me anymore. I moved in with my aunt and while living with her the story of my 
life changed when her husband started making passes at me. He started begging me that he will take me to anywhere I want. One day I was raped by him and from there I started allowing him to take me out because he is always providing me with goodies. I went out with him in the absence of my aunt who is always busy with work and also trusted with me with the husband so much. He took me to the club one day and that is where he introduced me to alcoholic drinks and smoking. I was given "shisha" to inhale and marijuana smokers were everywhere. I could not do without smoking "shisha" and also became an expert in it, which $i$ have not been able to recover from till now but the doctors are trying to help me. My aunt brought me here after discovering some drug intake symptoms in me. (Female17years)

One participant blamed his alcoholic lifestyle on his parent's separation. He was asked to live with a relative that is alcoholic where he was introduced to substance use. According to the narrative:

My parents are not together anymore and because of the fight between both of them, my grandmother took me to one of my uncles to stay with him, and pending the time the fight between my parents will be settled. My uncle will always send me to get cigarettes and beer for him and his friends. One of the friends gave me a beer to drink one day in the presence of my uncle and they were all laughing that I am a novice and that I do not know anything. (Male/16years)

Another participant gradually got involved in over-the-counter drug, which was originally intended to cure a cough. This was purchased for him by his mother. The participant did not at any-time mention his father; we assumed she was raised by a single parent. The after-effect of the drug kept her framing herself sick of a cough in order to have access to the cough syrup. According to her, she said:

When I was 13 years old, I had this coughing problem. My mother gave me benylin cough syrup to suppress and heal me of a cough. But whenever I take the drug, I always feel drowsy and 'high' at the same time. Anytime I came back from school, I will drink more than the recommended dose of the syrup because I am the only one in the house and my mother has gone to work. She complains that the drug is getting exhausted so quickly, that normally the drug is supposed to last me a week or two. After the syrup dosage, I love the later effect of the drug on me so, I pretend to still have a cough which my mother gave a neighbour to help me get the drug from the pharmacy. I became addicted and started taking the drug secretly (Female/17years).

She continued to explain how she further got exposed to mixing the substance with other drink. One of her boyfriends was already a substance abuser, so she was further strengthened to continue the practice.

\section{Single parenting and time factor}

The data revealed that parents who do not have time for their children could lead them into drugs. Also some parents socialise their male children into drugs as demonstrated by some of the participants.

A participant stated thus: 
I stay with only my mother and we are just two (a boy and a girl). I tried to get my mother's attention but all to no avail as she is always busy with one project or the other and with work. There was no time for us the children and I became lonely at some point in my life. Because she is not always around, I decided to go look out for my friends and have fun leaving only my sister in the house. As a result of no proper monitoring for me, I decided to go with my friends to experiment smoking of cigarettes. After sometimes, I decided to move into smoking of marijuana with my friends because they told me that cigarettes are for small boys. Sometimes, I will take marijuana raps home and hide in the bathroom to smoke it. It was fun having the experience as no one was there to monitor me including my sister because I told her I will kill her if she ever told mum. I never knew smoking of marijuana intake will get into my head as I became addicted to it. I started losing weight and behaving strangely. My mum took me to our family hospital where it was detected that I smoke and it has affected my internal organs including my brain. She transferred me here immediately for treatment that she can never allow me to stay with her. (Male/18years)

\section{Consequences of drug abuse}

All the participants at the time of the interview had been in the psychiatric ward for not less than 6 months. They had been addicted and affected by the substance they abused. However, data revealed some patters of abnormal behaviours that are labelled social dysfunction. Some of the participants, affirmed that involvement in drug abuse made them to become addicted, lost weight, became violent, restless, and got 'high' and under psychosis behaviour.

One participant narrating how he got addicted and began to steal his mother's money said:

I decided to take things to the next stage by going to the clubs with my friends. This eventually results in an addiction for me as I could not do a day without taking alcohol and I also steal my mum's money to get vodka. I do not have a good relationship with my parent especially my Dad as he believes that, we the children are our mother's responsibility to cater for, not his. (Male/18 years)

Another participant corroborated the view above and said his own behaviour became violent towards people:

I took both beer and cigarettes which later graduated to the intake of rohypnol and cannabis to get me 'high'. I could not stop the intake of these drugs anymore and these results in me becoming violent to people around me. I nearly fought with my uncle one day and this was because I was on drugs that day and did not really know what I was doing. My uncle and grandmother brought me here. (Male/16years)

Another participant narrated his experience as that of losing weight:

I wanted to tell my Mum the first night but was scared to say it in the present of my Dad. I later became addicted and always went to my neighbour apartment to get the stuff. I was losing weight and looking rough. This made my mother to take me to the hospital and it was discovered I have caffeine in my bloodstream. (Male/15years) 
The patterns shown in all our participants is that they were introduced to substance use and they gradually added some more substance and later became addicted. The abuse of the substances influenced their psychosocio behaviour.

\section{Discussion}

This study explored the experiences of adolescents' drug abusers in Lagos Nigeria. Specifically, we examined the role of peer influence and family disorganisation as factors of predisposition that can lead to their drug use, and the consequences of drug abuse.

The study re-emphasised the role of peer pressure in adolescents' drug abusing habits. In this study, the need or pressure to 'belong' or to be 'accepted' among their peers and have a sense of belonging is a major contributory factor why adolescents do drugs with and among peers. For them to continue to remain in the group, they must conform to the group values, norms and practices. Drawing from our study, $50 \%$ of the participants were pressured by peers to use drugs. The findings of this study are consistent with the works of Foo [1,3].

The findings demonstrated that the respondents had friends that take codeine, marijuana, tobacco, cannabis among other drugs and are therefore easily pressured into drugs if the friendship is to be sustained. This is in line with Oluremi submission that in Nigeria, and other parts of the world, one may not enjoy the company of others unless he conforms to their norms [34] and Shuttleworth - young people smoke because of peer pressure in order to "belong" and not appear "different" [32]. Similarly, a survey conducted by Kwada found that over $80 \%$ of senior secondary school students in Kafanchan in
Nigeria admitted that they abuse drugs because they wanted to feel among their peers [35].

Comments by participants in this study indicated how they become introduced to drug use. For example, one participant said... "But (we) were told that if we are not 'high' with alcohol or smoke marijuana, that the inspiration will not be there and that our performance will be bad". This is specifically true of performing artists; as Nwadigwe affirmed that alcohol and other substances abuse is an ongoing concern confronting drama school authorities and theatre workers in Nigeria [36]. This is because the use of drugs to enhance performance is becoming entrenched among performing artists. This is so according to McManus because performers do suffer from performance anxiety, otherwise known as 'stage fright' and many performers turn to stimulants to reduce such performance-related anxiety for improved presentation [37].

The findings show that the family provides a context for most young ones to take drugs. Specifically, the kind of family they grew up in, how it is structured, living with extended family members or significant others and conflict within the family can make an adolescent go into drug use. Most of the respondents indicated that not living with biological parents can make a child become wayward and engage in delinquent acts, most respondents who live with their aunts, granny or uncles, lacked adequate supervision and care and some even picked up drug habit from those they live with. According to this study, seventeen of them stayed in dysfunctional homes, which they indicated as the cause of their drugs intake. This is line with Chikezie that found that participants from polygamous homes and dysfunctional fami- 
lies were found to be taking alcohol currently more than those from monogamous and stable families [23].

The study found that most of the adolescents were faced with unresolved issues arising from family disorganisation or living in an empty shell family. The abuse of drugs by adolescents from such families is to them escaping the trauma and consequences of living in such a family but this has its latent consequences for the individual. In such families both parents are hardly united on how children should be raised and who takes responsibility for what. Some are from polygamous homes, where in most cases the wives live separately from the man in different locations and in some cases they all live together in one compound. In this kind of situation, the woman is left alone to raise the children and in situation where the woman is incapable, especially financial commitment, the child will be left to fend for himself or herself and in the process join different groups or even gangs where his or her behaviour can easily be corrupted.

Our study found that irrespective of the structure of the family or parenting status, adolescents still go into drug abuse. This may partly be explained by the fact that in most cases both parents will go out to work in order to fend or provide for the family because of the present economic predicament and in the process, neglect their duties to their children and have little or time for their children.

The study found that children or adolescents that grow up witnessing domestic violence between their own parents may likely indulge in drug abuse. The process is such that anytime there was a physical or even verbal abuse between the parents, the children feel discomforted seeing their parents fighting, the home environment at that particu- lar time becomes uncondusive for them to remain and, hence, they leave the home for where they can find 'peace' at that particular time. In the process of finding peace, they run to individuals or fellow adolescents who may be experiencing such situations and in the process get introduced into drugs. Some of the adolescents are also victims of violence either physical or verbal and go into drugs to make them forget about their troubles at home; to also help them build their self-esteem and become more courageous.

There are limitations in the interpreting of the result from this study. First, the sample was small and geographically limited to drug abuse adolescents undertaking treatments in a psychiatry ward, Lagos Nigeria. Second, the views and experiences shared by the participants cannot be generalised to other adolescents' drug abusers in other settings. Third, the interpretation lenses used in exploring the adolescent drug abusers here are based on their explanations of their life experiences and may not necessarily be the same with other peoples'experiences. Despite the limitations of the study, findings from the study contribute to knowledge on the social interaction experienced by the drug users, factors that lead to their drug use and abuse, and the consequences of drug abuse.

\section{The Role of Psychiatry Hospital in the Treament and Prevention of Drug Abuse in Nigeria}

Pychiatry hospital in Nigeria remains a critical agent of drug prevention and control in the developing countries but the limited role of this agency and the increasing number of people who take drugs in these countries indicate that governments still have a long way to go in combating the problem in the developing world. Although, drug prevention 
programmes may be very low in a developing country like Nigeria, the presence of psychiatry hospitals and the treatment of drug patients have continued to rekindle hope in the friends and family members of drug abusers in Nigeria that they will return to normal life. This is not say that aggresive community service is not needed to effectively control the problem of drug abuse in developing countries including Nigeria [38].

\section{Conclusion}

Despite the overwhelming evidence of social and health implications of drug abuse in our society, adolescents are being socialized into the use and abuse of drug on a daily basis. This is so because of parental neglect, association with alcoholic relatives and friends and the need to belong to peer group. Coincidentally, all the participants in this study are undergoing treatment in a psychiatric hospital as a result of the negative effect of drug abuse. Cultural use of alcohol, access to over the counter drugs without a prescription, association with drug abusers and relatives involving youth in purchasing

\section{References}

1. Foo YC, Tam CL, Lee TH. Family factors and peer-pressure influence in drug abuse: a study in rehabitation centre. Int J Collab Res Intern Med Public Health. 2012;4:189-201.

2. Jorge KO, Ferreira R, Ferreira E, Kawachi I, Zarzar PM, Pordeus IA. Peer Group Influence and Illicit Drug Use among Adolescent Students in Brazil: A Cross-Sectional Study, Reports in Public Health [Internet]. 2018 [cited February 27 $7^{\text {th }} 2019$ ]. Avaible from: http://www.scielo.br/pdf/csp/ v34n3/1678-4464-csp-34-03-e00144316.pdf. drug should be discouraged. This can be followed up with policy gear towards adolescent as a strategy for preventing exposure to illicit drugs, from the insight of this study rather than later when psychosis is experienced. If this cycle of drug use and addiction is not broken, addiction problem may compound in the future. The government should formulate policy that will educate both adolescents and parents not just on the consequences of drug abuse but also on the need to prevent those factors that predisposes individuals to doing drug. Efforts should be put in place to care for children who are victims of family disorganisation or broken homes. There is also the need for continuous sensitization about the harmful effects of drugs and parents should be educated on the danger of having a family that is disorganised.

\section{Acknowledgements}

None.

\section{Conflicts of interest}

None to declare.
3. Somani S, Meghani S. Substance Abuse among Youth: A Harsh Reality. Emerg med. 2016;6:4.

4. Akannam T. North-West rank highest in drug addiction. Nigerian Drug Statistics by Zone [Internet]. 2008 [cited February $27^{\text {th }}$ 2019]. Avaible from: https://www.nairaland.com/203955/nigeriandrug-statistics-zone

5. National Institute on Drug Abuse. Principles of adolescent substance use disorder treatment: a research-based guide [Internet]. 2014 [cited March $\left.13^{\text {th }} 2019\right]$. Avaible from: https://d14rmgtrwzf5a.cloudfront.net/sites/default/files/podata_1_17_14.pdf 
6. Bassi AP, Idoko L, Ogundeko TO, Ramyil MSC, Abisoye-Ogunniyan A, Ogbole EA, Thilza SA, SuleUredo'ojo, Ante E. Bassey, Baba A. Ishaku,Chimbuoyim Iheanacho N. Substance abuse and its prevalence among secondary school adolescents in Kagoro, Kaduna State, Nigeria. World J Res Rev. 2017;5:11-6.

7. National Drug Law Enforcement Agency. Drug free club [Internet]. 2009 [cited March 11 ${ }^{\text {th }}$ 2019] Avaible from: www.ndlea.gov.ng

8. Chukwujekwu CD. Psychoactive substance use among Nigerian students; patterns and socio-demographic correlates. Am J Psychiatry Neurosci. 2017;5:22-5.

9. Gotsang G, Mashalla Y, Seloilwe E. Perceptions of school going adolescents about substance abuse in Ramotswa, Botswa. J Public Health Epidemiol. 2017;9:151-60.

10. Mamman H, Othman AT, Lian HL. Adolescent's and drugs abuse in Nigeria. J Biol Agric Healthc. 2014;4:5-9.

11. United Nations Office on Drugs and Crime. World Drug Report [Internet]. 2014 [cited March 16th 2018] Available from: https://www.unodc.org

12. Nigeria Stability and Reconciliation Programme (NSRP). Policy Brief: How an improved understanding of drug use can contribute to peace and stability in Nigeria [Internet]. 2017 [cited March 11 ${ }^{\text {th }}$ 2019] Available from https://www.nsrp-nigeria.org

13. Alemika EEO. Narcotics drugs control policy in Nigeria. Ibadan: Development Policy Centre; 1998.

14. Ani GN. Prevalence of substance abuse among senior secondary students in Mainland local government, Lagos. Glob J Med Pub Health. 2014;3.

15. Abasiubong F, Udobang JA, Idung AU, Udoh $\mathrm{SB}$, Jombo HE. A comparative study of pattern of substance use in two Nigerian cities located in the southern and northern Nigeria. Afr Res Rev. 2014;8:52-67.

16. Adeyemo FO, Ohaeri B, Pat UO, Ogodo O. Prevalence of drug abuse amongst university students in Benin City, Nigeria. Public Health Res. 2016;6:317.

17. Ayomide OT. Codeine the favourite drink of $\mathrm{Ni}$ gerian drug users [nternet]. 2017 [cited April 16th 2019] Available from: https://www.pulse.ng/gist/ codeine-the-favourite-drink-of-nigerian-drug-users/vn8msjf

18. Ayomide OO, Olalekan O. Revealed: Deadly cocktail of drugs now ravaging Lagos youths. The Tribune Newspaper [Internet]. 2016 [cited March 16th 2018] Available from:https://tribuneonlineng.com/revealed-deadly-cocktail-drugs-nowravaging-lagos-youths/

19. The Punch newspaper. Menance of rising drug abuse [Internet]. 2017 [cited March 16th 2018] Available from: https://punchng.com/menace-ofrising-drug-abuse/

20. Rask K Astedt-Kurki P, Laippala P. Adolescent subjective well-being and realized values. J Adv Nur. 2009;3:54-63.

21. Flewelling RL, Bauman KE. Family structure as a predictor of initial substance use and sexual intercourse in early adolescence. J Marriage Fam. 1990;52:171-81.

22. Krohn M. Family transitions and later delinquency and drug use. J Youth Adolesc. 2009;38:466-80.

23. Chikezie UE, Uzoeghe IU. Alcohol use among full-time students of the University of Abuja. Int J Emerg Ment Health. 2015;17:283-7.

24. Skeer M, McCormick MC, Normand SL, Buka SL, Gilman SE. Prospective study of familial conflict, psychological stress, and the development of substance use disorders in adolescence. Drug Alcohol Depend. 2009;104:65-72.

25. Ajidahun OB. Impact of psychosocial factors on adolescents' behaviour. Creat Educ. 2011;2:398401.

26. Abar B, Carter KL, Winsler A. The effects of maternal parenting style and religious commitment on self-regulation, academic achievement, and risk behavior among African-American parochial college students. J Adolesc. 2009;32:259-73.

27. Bailey JA, Hill KG, Oesterle S, Hawkins JD. Parenting practices and problem behaviour across three generation: monitoring harsh discipline, and drug use in the generational transmission of externalizing behavior. Dev Psychol. 2009;45:1214-26.

28. Hawkins JD, Catalano RF, Miller JY. Risk and protective factors for alcohol and other substance problems in adolescence and early adulthood: implications for substance abuse prevention. Psychol Bull. 2012;112:64-105. 
29. Straus MA. Beating the devil out of them: corporal punishment in American families. New York: Lexington Books; 1994.

30. Agunbiade OM. Workplace hazards and social positioning efforts of male adolescent labourers in sawmills, Lagos State Nigeria. Afr Sociol Rev. 2015;19:88-109.

31. Peer N. There has been little progress in implementing comprehensive alcohol control strategies in Africa. Am J Drug Alcohol Abuse. 2017;43:6315.

32. Kelly C, McCreadie RG. Smoking habits, current symptoms and primordial characteristics of schizophrenia patients in Nithsdale, Scotland. Am J Psychiatry. 1999;3:1751-7.

33. Braun V, Clark V. Using thematic analysis in psychology. Qual Res Psychol. 2006;3:77-101.

34. Oluremi DF. Drug abuse among Nigerian adolescents strategies for counselling. J Int Soc Res. 2012;5:342-7.
35. Kwada M. Prevalence and patterns psychoactive substance among students in Northern Kaduna. Int J Ad. 2008;2:1059-75.

36. Nwadigwe CE. 'I want to be a star': doping technology and the incidence of performance-enhancing drugs among actors in Nigeria. Afr Sociol Rev. 2008;12:144-54.

37. McManus D. Performance enhancing drugs for Musicians? [Internet]. 2017 [cited January 7th 2017] Available from: http://www.partialobserver. $\mathrm{com} /$ article.cfm?id $=1251$

38. World Health Organisation. Substance Use Problems in Developing Countries [Internet]. 2018 [cited March 17th 2018] Available from: https:// www.who.int/bulletin/volumes/82/9/editorial$20904 \mathrm{html} / \mathrm{en}$.

\section{Određuju li vršnjački i obiteljski čimbenici zlouporabu droga? Glasovi adolescenata liječenih na psihijatrijskom odjelu u Lagosu, Nigerija}

Sažetak - lako postoji mnogo studija o zlouporabi droga među adolescentima, postoje ograničeni radovi o životnim iskustvima ovisnika o drogama, podvrgnuti liječenju na psihijatrijskim odjelima u Lagosu, Nigerija. Ova studija istražila je iskustva ovisnika o drogama na to jesu li obitelji i vršnjaci faktori predispozicije i posljedica zlouporabe droga u Lagosu, Nigerija. Metode: koristeći svrhovito uzorkovanje, 20 adolescenata koji su primali medicinsku pomoć najmanje 6 mjeseci na psihijatrijskom odjelu nastavne bolnice sudjelovali su u dubinskim intervjuima koji su snimljeni audio zapisom. Podaci su sadržajno analizirani pomoću istraživačkog dizajna. Rezultati: Sudionici su bili u dobi od 14 do 18 godina, i svi su bili na psihijatrijskom liječenju u bolničkom odjelu. Otkrića su pokazala da su sudionici pod pritiskom vršnjaka uzeli drogu radi poboljšanja performansi, zanemarivanja roditelja i rodbine koji koriste ili zloupotrebljavaju neku supstancu. Sudionici su između ostalog zloupotrebljavali ilegalne droge. Posljedično, postali su ovisni, što je negativno utjecalo na njihovo ponašanje. Svi sudionici izvijestili su da su odvedeni na psihijatrijski odjel zbog ovisnosti o određenoj psihoaktivnoj drogi koja je utjecala na njihovo kognitivno ponašanje. Zaključak: Postoji potreba za kontinuiranom senzibiliziranjem svih građana o štetnim učincima zlouporabe droga. Roditelje bi također trebalo educirati o potrebi postojanja odgovornosti za brigu o njihovim štićenicima. Ovi nalazi imaju posljedice na prekid ciklusa ovisnosti o drogama i kako spriječiti buduće probleme zbog zlouporabe droga među adolescentima.

Ključne riječi: zloupotreba droga, adolescenti, vršnjački pritisak, Nigerija, nasilje u obitelji 
